The influence of system interactivity and technical support on learning management system utilization

Sousan Baleghi-Zadeh Ahmad Fauzi Mohd Ayub

Rosnaini Mahmud

Shaffe Mohd Daud

Universiti Putra Malaysia, Malaysia

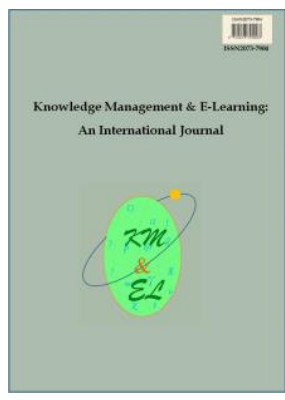

Knowledge Management \& E-Learning: An International Journal (KM\&EL) ISSN 2073-7904

Recommended citation:

Baleghi-Zadeh, S., Ayub, A. F. M., Mahmud, R., \& Daud, S. M. (2017). The influence of system interactivity and technical support on learning management system utilization. Knowledge Management \& E-Learning, 9(1), 50-68. 


\title{
The influence of system interactivity and technical support on learning management system utilization
}

\author{
Sousan Baleghi-Zadeh* \\ Faculty of Educational Studies \\ Universiti Putra Malaysia, Malaysia \\ E-mail: s_baleghi@yahoo.com
}

\begin{abstract}
Ahmad Fauzi Mohd Ayub
Faculty of Educational Studies Institute For Mathematical Research Universiti Putra Malaysia, Malaysia E-mail: afmy@upm.edu.my
\end{abstract}

\section{Rosnaini Mahmud}

Faculty of Educational Studies Institute For Mathematical Research Universiti Putra Malaysia, Malaysia

E-mail: rosnaini@upm.edu.my

\section{Shaffe Mohd Daud}

Faculty of Educational Studies Institute For Mathematical Research Universiti Putra Malaysia, Malaysia E-mail: shaffee@upm.edu.my

*Corresponding author

\begin{abstract}
In recent years, there has been a growing increase in using Learning Management System (LMS) by universities. However, its utilization by students is limited in Malaysia. The main purpose of the present study is to develop and test a model that predicts LMS utilization by Malaysian higher education students. Based on the Technology Acceptance Model, the study investigated the relationships among six constructs (system interactivity, technical support, perceived ease of use, perceived usefulness, behavioral intention to use and LMS use) through structural equation modelling. The participants were 216 undergraduate students from a local university in Malaysia. The result of the study revealed that system interactivity had a significant effect on perceived usefulness, but not on perceived ease of use; technical support had a significant effect on perceived ease of use, but not on perceived usefulness.
\end{abstract}

Keywords: Technology acceptance model; Learning management system; System interactivity; Technical support; Structural equation modelling 
Biographical notes: Sousan Baleghi-Zadeh is a secondary teacher, teacher educator, and researcher at the Ministry of Education in Tehran, Iran for more than 20 years. She completed her Ph.D. studies in Educational Technology, at the Universiti Putra Malaysia. She has published on e-learning and learning management system. She is currently supervising M.A. theses at Islamic Azad University, Central Branch, Tehran, Iran.

Dr. Ahmad Fauzi Mohd Ayub is an Associate Professor in the Faculty of Educational Studies, Universiti Putra Malaysia. He has been involved in doing research in the areas of technology education, e-learning, mobile learning and multimedia education. He also has published papers as main author and coauthor of various papers related to technology in education, focusing mainly on ICT literacy and its use among school teachers and students. He has written papers on the use of learning management systems, integration of computer software in teaching and learning.

Dr. Rosnaini Mahmud is a senior lecturer in the Faculty of Educational Studies, University Putra Malaysia. She is involved in various researches related to her expertise and area of interests particularly ICT and resources in education, educational technology, instructional design, ICT integration, game-based learning and technology-enhanced pedagogies. In terms of publication, she has authored and co-authored various journal articles, chapters in books, monograph, proceeding papers and training modules related to utilization and impact of technology in teaching and learning. She is also involved in consultancy and research activities related to designing, development and utilization of multimedia and e-learning.

Dr. Shaffe Mohd Daud, is a senior lecturer at the Educational Technology Unit, Faculty of Educational studies, Universiti Putra Malaysia. He has served as a teacher, teachers educator, assistant director, head assistant director at Ministry of Education before became a lecturer at UPM. He has been involved in research and consultancy works, and publication in the area of Educational Technology and Distance Education, especially in video conferencing.

\section{Introduction}

In recent years, the rapid growth of Information and Communication Technologies (ICT) has affected various aspects of life in general and education in particular. An important point that needs consideration is that the growth of technology has reached a stage where it can produce new concepts and terms that did not exist before (Folden, 2012). One of the popular concepts that ICT has produced in the realm of education is e-learning (Hernandez, Montaner, Sese, \& Urquizu, 2011; Šumak, Heričko, \& Pušnik, 2011). Systems that conduct e-learning are different and have various names such as online systems, virtual systems, learning management systems and so on (Connolly, Gould, Baxter, \& Hainey, 2012; Piotrowski, 2010). To benefit from this new facility in education, many universities and schools worldwide have been equipped with learning management systems (LMS) within the last few years (Piotrowski, 2010). Today, LMS is very popular in that its usefulness in higher education institutions is substantially increasing (Álvarez, Martín, Fernández-Castro, \& Urretavizcaya, 2013; Dutta, Roy, \& Seetharaman, 2013; Islam, 2013). LMS supports the process of teaching and learning. For example, through the features of LMS, instructors and students can convey instructional materials, send notice to class, submit assignments, and interact with students (Lonn \& 
Teasley, 2009). In fact, this information system combines technology features with pedagogy (Ioannou \& Hannafin, 2008). Nevertheless, it is often used for delivery of contents (Álvarez et al., 2013; Stantchev, Colomo-Palacios, Soto-Acosta, \& Misra, 2014).

In Malaysia, developing strategies of e-learning began in 1996 (Puteh, 2007). In 2012, most of Malaysia's Higher Education institutions were equipped with LMSs developed by themselves (Ayub, Tarmizi, Jaafar, Ali, \& Luan, 2010; Lee, Chan, Thanimalay, \& Lim, 2012). In 2011, the Malaysian Ministry of Higher Education carried out a study to investigate the status of e-learning in 30 universities of Malaysia equipped with LMS (Embi, Wahab, Sulaiman, \& Atan, 2011). The results of this study revealed that most of the lecturers and students believed that the features of chat and bookmarking were not useful. One of the main challenges detected was lack of technical support.

A strong model of LMS utilization will help universities and organizations to enhance their knowledge of individual management (Chang, 2008). Studies in the domain of system utilization are also important to evaluate the success of a system (Álvarez et al., 2013). Therefore, organizations will be able to overcome the limitations of systems in order to enhance the quality of learning activities (Ku, 2009). Hence, the objectives of the present study are:

1. To determine the factors that may affect LMS utilization among Malaysian Higher Education students

2. To develop and test a model for LMS acceptance, incorporating system interactivity, and technical support

\section{Literature review}

In Malaysia, most of the studies on examining predictors of LMS utilization either focus on descriptive statistics (e.g., by reporting mean, standard deviation, etc.), multiple regression, etc., or are simply literature reviews. As a result, complicated procedures for data analysis such as mediation test and path analysis are less frequently used (Adzharuddin \& Ling, 2013; Ayub et al., 2010; Hilmi, Pawanchik, \& Mustapha, 2012; Rahman, Ghazali, \& Ismail, 2010). Although mediation analysis is a powerful statistical technique for understanding the relationship between variables (Hair, Hult, Ringle, \& Sarstedt, 2014; Kenny, 2014), reviewing the related literature (searching databases such as Science Direct EBSCO, springer, Emerald) showed that there are only a few studies in Malaysia which have employed this technique for investigating the relationship between the variables. One of the powerful models that allows researchers to investigate multiple relationships between mediators and independent variables is Technology Acceptance Model (Venkatesh \& Bala, 2008). However, there are very few studies that have used this model for investigating factors that influence LMS use.

Technology Acceptance Model (TAM) is one of the popular and powerful models in studying factors affecting utilization of an information system (Igbaria, Guimaraes, \& Davis, 1995; Venkatesh \& Bala, 2008). TAM was introduced by Davis (1986), who adopted its foundation from the Theory of Reasoned Action (TRA), which is one of the models of social psychology proposed by Fishbein and Ajzen (1975). Based on TAM, using information systems by individuals depends on two key variables: perceived ease of use (PEU) and perceived usefulness (PU) (Davis, Bagozzi, \& Warshaw, 1989). Perceived usefulness is the degree to which an individual believes that using a system will increase his/her performance (Davis et al., 1989; Ngai, Poon, \& Chan, 2007). Perceived ease of use is the degree to which an individual thinks that using the system is 
free of effort (Davis et al., 1989; Ngai et al., 2007). Therefore, in the domain of education, students and teachers should perceive the usefulness of technological tools in supporting learning activities and achieving academic goals. On the other hand, technology should be free of efforts (Davis et al., 1989; Ngai et al., 2007).

As Fig. 1 shows, in the primary technology acceptance model, external variables, perceived ease of use, perceived usefulness, attitudes and intentions were connected to each other (Davis, 1986).

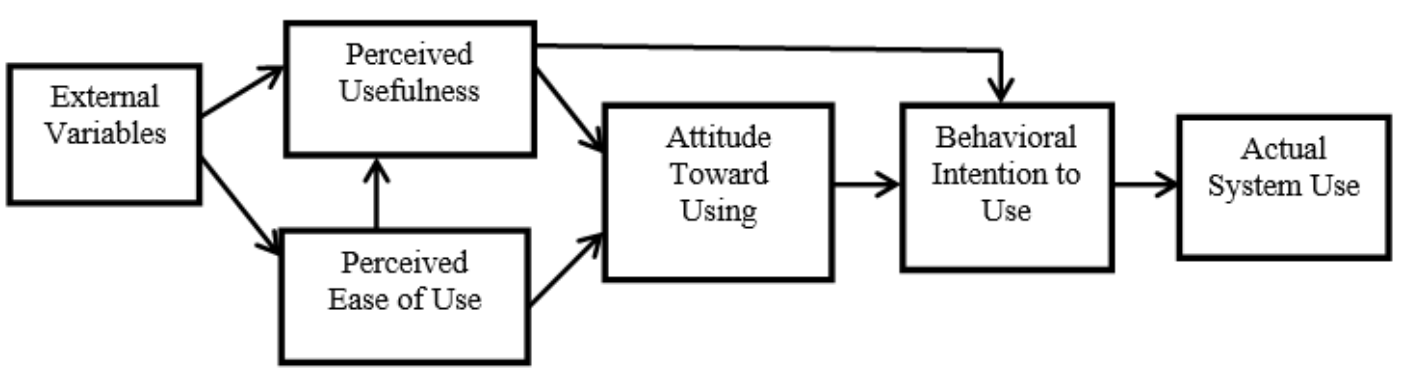

Fig. 1. Technology acceptance model (primary model). Adapted from Davis et al. (1989)

In a final model, Davis et al. (1989) after testing the previous models, excluded attitudes toward use, because as a mediator, this construct had a poor influence between beliefs (perceived ease of use and perceived usefulness) and behavioral intention to use (see Fig. 2). Therefore, in the present study, behavioral intention to use, perceived ease of use and perceived usefulness, which were considered as internal factors that may affect LMS utilization and attitude toward using it, were removed.

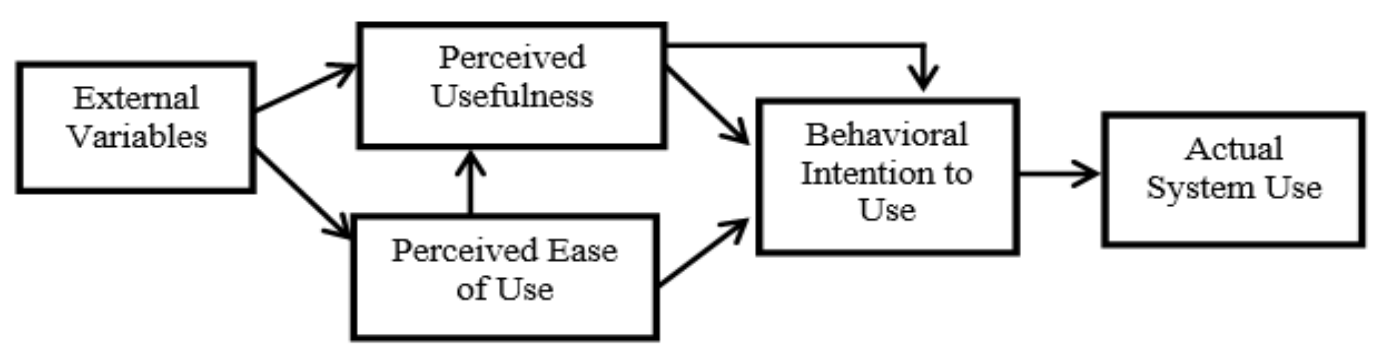

Fig. 2. Revised technology acceptance model (after testing the model)

In the original Technology Acceptance Model, the external variables were not specified, but Davis et al. (1989) implied that they could encompass different intervention variables such as system features, user training and user support consultants which may have a key role in determining system utilization (Davis et al., 1989). However, there are different external variables which may affect system utilization. In the present study by considering the relevant literature two external variables (system interactivity and technical support) were selected and their influence on LMS utilization was investigated.

\subsection{System interactivity}

In recent years, LMS capacities have provided a platform which breaks the limitations of time and space for communication. System interactivity facilitates relationship between 
learners and lecturers (Sun \& Hsu, 2013). The features of online interactivity will also enable lecturers to create social online tasks and manage learners' interest and their quality of learning (Rodríguez-Ardura \& Meseguer-Artola, 2015). Interactivity has different aspects. For example, Su, Bonk, Magjuda, Liu, and Lee (2005) considered interactivity as features of the media. Thurmond and Wambach (2004) regarded the aspect of learner-learner interactivity. This aspect of interactivity motivates interpersonal communication and knowledge exchange (Chou, 2003). Bannan-Ritland (2002) and Northrup (2002) focused on learner-self interaction. This capacity of interactivity describes how learners explore and build knowledge and enhance individual learning (Northrup, 2002). Moore (1989) defined learner-content interaction as learning through course content. However, in LMS environment interactivity has been identified as exchanging knowledge between users through media with the goal of increasing the quality of learning (Chou, 2003; Thurmond \&Wambach, 2004). Therefore, in the present study, system interactivity is defined as the ability of the system to provide opportunities for interaction among users (Pituch \& Lee, 2006).

\subsection{Technical support}

Another external variable of the study is technical support which is sometimes called facilitating conditions or organizational support (Davis et al., 1989; Venkatesh \& Bala, 2008). Technical support enhances satisfaction of users and has a critical effect on users' beliefs in accepting or rejecting an information system (Igbaria et al., 1995; Venkatesh \& Bala, 2008). When users receive no help from the assistants while being faced with a problem, they will get the feeling that working with the system is a waste of time and hence will quit working with it (Dżega \& Pietruszkiewicz, 2012). Although technical support is one of the important factors that may influence LMS utilization, there is a paucity of empirical research that has investigated its influence on LMS use (Al-Busaidi \& Al-Shihi, 2012). This is particularly important in the context of Malaysia, since there only a few researchers who have investigated the role of technical support on LMS use (Adzharuddin \& Ling, 2013; Sulaiman, 2013). In the present study, technical support refers to assisting people to solve problems students encounter when they are working with an information system (Ngai et al., 2007).

\section{Research model and hypothesis}

Based on TAM and literature review, the proposed model of the present study includes three internal factors (perceived ease of use, perceived usefulness, behavioral intention to use) and two external factors (system interactivity and technical support) which may affect LMS utilization. Fig. 3 illustrates the relationship between the constructs of the study.

The results of previous studies revealed that interactivity is a crucial factor which affects positive attitude, quality of learning, and motivation (Evans \& Gibbons, 2007; Grigorovici, Nam, \& Russill, 2003; Sundar, Kalyanaraman, \& Brown, 2003; Thorson \& Rodgers, 2006). For example, Proske, Narciss, and Korndle (2007) found interaction through LMS improved the quality of learning. According to Ke, Sun, and Yang (2012), lack of system interactivity would have a negative influence on interaction between users and consequently system acceptance.

In the realm of Technology Acceptance Model, the results of previous studies in investigating the effect of system interactivity on users' beliefs (perceived ease of use and 
perceived usefulness) are not consistence. For example, Pituch and Lee (2006) investigated the influence of system characteristics on LMS utilization among 259 participants in Taiwan and found that system interactivity had a significant influence on perceived usefulness, while its influence on perceived ease of use was not significant. However, Ke et al. (2012) in investigating the influence of system interactivity on webbased classroom system showed that system interactivity had a significant effect on both perceived ease of use and perceived usefulness. Therefore, the following hypotheses were proposed:

H1. System interactivity has a significant effect on perceived usefulness

$\boldsymbol{H}$ 2. System interactivity has a significant effect on perceived ease of use

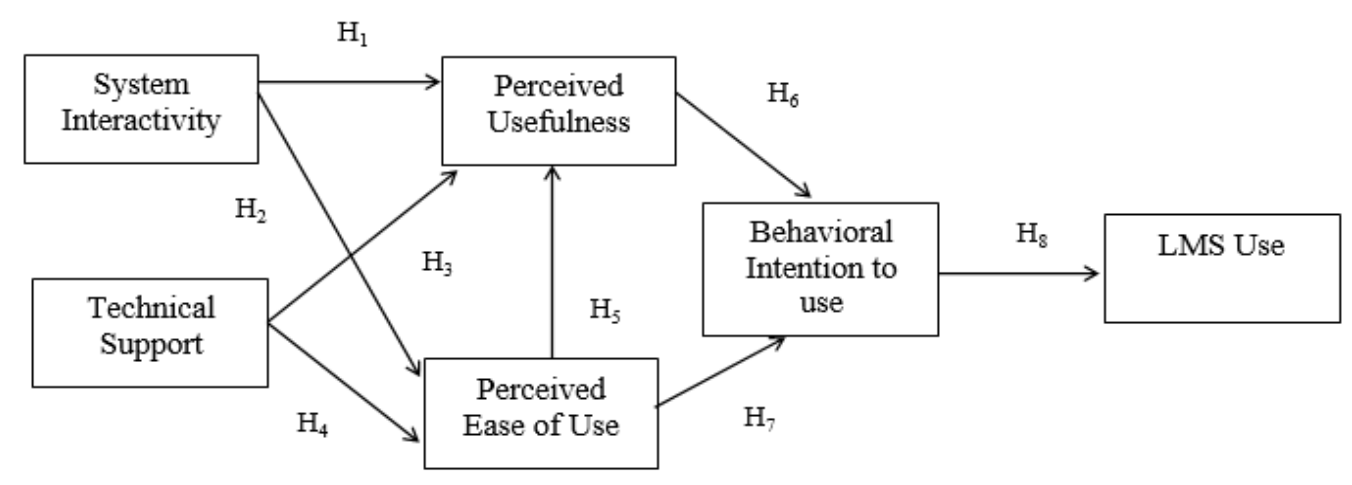

Fig. 3. The proposed research model

As mentioned above, the term technical support which is used along with different terms such as facilitating conditions or organizational support has an important role in determining beliefs, namely perceived ease of use and perceived usefulness (Ngai et al., 2007; Sánchez \& Hueros, 2010). For example, Ma, Chan, and Chen (2016) in investigating smartphones' acceptance among 120 Chinese older adults (over 55) found facilitating conditions has a crucial role in determining perceived usefulness and perceived ease of use. Nair, Ali, and Leong (2015) in examining lecture capture system (LCS) - ReWIND acceptance among 398 Malaysian higher education students found facilitating conditions had a significant effect on intention to use ReWIND. The results of empirical studies also show that technical support has a positive influence on motivation and behaviors of users (Futris, Schramm, Richardson, \& Lee, 2015; Nijman \&, Gelissen, 2011). Therefore, the following hypotheses were formulated:

\section{H3. Technical support has a significant effect on perceived usefulness}

\section{H4. Technical support has a significant effect on perceived ease of use}

As Fig. 1 shows, in the original TAM beliefs (perceived ease of use and perceived usefulness) were regarded as predictors of behavioral intention to use; perceived ease of use as predictor of perceived usefulness; and behavioral intention to use as predictor of system use (Davis et al., 1989). In other words, behavioral intention to use mediated the influence of beliefs (perceived ease of use and perceived usefulness) on system utilization.

In fact, behavioral intention to use is the power of an individual's intention in performing a specific behavior (Davis et al., 1989). TAM considers behavioral intention to use as a determiner of system utilization. The outcomes of testing the original TAM 
revealed that this variable is a bridge between beliefs (perceived ease of use and perceived usefulness) and system utilization. Thus, the result of testing TAM showed that behavioral intention to use had the role of mediation between beliefs and system utilization. This result is also confirmed by testing Technology Acceptance Model 2 and Technology Acceptance Model 3 (Venkatesh \& Davis, 2000; Venkatesh \& Bala, 2008). On the other hand, there are several studies which found beliefs (perceived ease of use and perceived usefulness) had a significant effect on behavioral intention to use. Several studies also showed that there was a significant effect between behavioral intention to use and system use. For example, Motaghian, Hassanzadeh, and Moghadam (2013) examined LMS utilization among 115 Iranian university instructors and found there was a significant effect between beliefs (perceived ease of use and perceived usefulness) and behavioral intention to use. The result of this study also showed that behavioral intention to use had a significant effect on LMS use. In other words, behavioral intention to use mediated the influence of beliefs on LMS use.

Klopping and McKinney (2004) investigated the acceptance of e-commerce among 263 undergraduate students and found there was a significant effect between behavioral intention to use and system use. This study also revealed that beliefs (perceived ease of use and perceived usefulness) had a significant effect on system use. Still in another study, Wang and Wang (2009) investigated LMS utilization among 259 Taiwanese instructors and found there was a significant effect between behavioral intention to use and LMS use. Ghavifekr and Mahmood (2017) investigated the effect of behavioral intention to use of Spectrum (LMS of University of Malaya) among 120 undergraduate and graduate Malaysian students and found behavioral intention to use had a significant influence on LMS use. Therefore, the following hypotheses were proposed:

\section{H5. Perceived ease of use has a significant effect on perceived usefulness \\ H6. Perceived usefulness has a significant effect on behavioral intention to use \\ H7. Perceived ease of use has a significant effect on behavioral intention to use \\ H8. Behavioral intention to use has a significant effect on LMS use}

\section{Research method}

\subsection{Development of the instrument}

The instrument used in the present study was a questionnaire with 31 items. Among these items, eight were self-developed and 23 were adopted from previous validated instruments. Six experts on education at Universiti Putra Malaysia (UPM) examined the content validity of the instrument and their comments were followed. Table 5 reports the items and the sources from which the 31 items were extracted. The constructs of perceived usefulness, perceived ease of use, behavioral intention to use, technical support, and system interactivity were measured through five-point Likert-scale items labeled as 1 (strongly disagree), 2 (disagree), 3 (not sure), 4 (agree) and 5 (strongly agree), while the construct of LMS use was measured through five-point Likert-scale items labeled as 1 (not at all), 2 (once per semester), 3 (once a month), 4 (once a week) and 5 (every day).

The instrument was also pilot tested on a sample of 40 undergraduate students in order to identify any potential problems which may impact on the outcomes of the main study (Blessing \& Chakrabarti, 2009; Offredy \& Vickers, 2010). To measure the reliability of the instrument, Cronbach's alpha was used. As Table 1 shows, the range of 
Cronbach's alpha for the six constructs of the present study was from 0.87 to 0.92 , which are favourable (Leech, Barrett, \& Morgan, 2008).

Table 1

Cronbach's alpha coefficient of the constructs in the pilot study

\begin{tabular}{lcc}
\hline \multicolumn{1}{c}{ Construct } & Cronbach's alpha & Number of items \\
\hline Perceived ease of use & $87 \%$ & 4 \\
Perceived usefulness & $92 \%$ & 7 \\
Behavioral intention to use & $90 \%$ & 6 \\
System interactivity & $86 \%$ & 4 \\
Technical support & $82 \%$ o & 4 \\
LMS use & $89 \%$ & 6 \\
\hline
\end{tabular}

\subsection{Data collection}

The design of the present research was a survey study. A survey is a systematic method of gathering data from a number of participants (Krysik \& Finn, 2010). The participants of the present study were 216 full time undergraduate students at the faculty of educational studies in the second semester of the academic year 2012-2013 selected through cluster sampling. UPM is one of the public universities in Malaysia located in the province of Selangor. It has the largest number of bachelor students in the faculty of education. PutraLMS was developed by local vendors and was subsequently launched (Hamat, Embi, \& Sulaiman, 2011; Putra Learning Management System, 2013). In addition, Using PutraLMS is not compulsory at UPM. In the demographic questions, we asked students if using LMS in their courses were compulsory. About 90 percent of the students responded that using LMS was not compulsory. However, 10 percent of the students responded that using LMS was obligatory in some courses.

\subsection{Demographics and descriptive statistics}

As Table 2 shows, among the 216 respondents, 37 (17.1\%) were male and $179(82.9 \%)$ were female. The majority of the respondents were Malay $(82.4 \%)$ followed by Chinese $(8.3 \%) .91 .5 \%$ of respondents reported that they never attended any workshop or course for using LMS.

Table 2

Demographic information

\begin{tabular}{lcccccccc}
\hline & \multicolumn{2}{c}{ Gender } & \multicolumn{2}{c}{ Age (by years) } & \multicolumn{4}{c}{ Race } \\
& Male & Female & $19-24$ & $25-30$ & Malay & Chinese & Indian & Others \\
\hline Frequency & 37 & 179 & 209 & 7 & 178 & 18 & 9 & 11 \\
Percentage (\%) & 17.1 & 82.9 & 96.8 & 3.2 & 82.4 & 8.3 & 4.2 & 5.1 \\
\hline
\end{tabular}

Table 3 reports the mean and standard deviation, kurtosis and skewedness of each variable. As Table 3 shows, among undergraduate students, behavioral intention to use of PutraLMS was high. Additionally, students generally believed that PutraLMs was userfriendly and also productive for their learning activities. 
Table 3

Descriptive statistics

\begin{tabular}{ccccc}
\hline Construct & Mean & Standard Deviation & Kurtosis & Skewedness \\
\hline Perceived ease of use & 3.76 & .67 & .532 & -.751 \\
Perceived usefulness & 3.74 & .72 & .783 & .792 \\
Behavioral intention to use & 3.61 & .84 & .248 & -.797 \\
Technical support & 3.35 & .69 & .393 & -.306 \\
System Interactivity & 3.53 & .78 & .422 & -.526 \\
LMS use & 2.90 & .84 & -.941 & .069 \\
\hline
\end{tabular}

\section{Data analysis and results}

To examine the hypotheses of the present study, structural equation modelling (SEM) was used. In general, SEM is divided into two sub-models: the measurement model and the structural model (Ho, 2006; Wang \& Wang, 2012).

Table 4

Fit indices of measurement model

\begin{tabular}{llll}
\hline Model Fit Indices & Criteria & Values & References \\
\hline$\chi^{2}$ & $\begin{array}{l}\text { Insignificant, significant } \\
\text { value can be expected }\end{array}$ & Insignificant & Hair et al. (2010) \\
& $=<2$ & 1.630 & Im and Grover (2004) \\
$\chi 2 / \mathrm{df}$ & .870 & $\begin{array}{l}\text { Schumacker and Lomax } \\
(2010)\end{array}$ \\
GFI & Near to .90 & & Im and Grover (2004) \\
AGFI & $=<.08$ & .806 & Marsh, Hau, and Wen (2004) \\
IFI & Near to .90 & .945 & Schumacker and Lomax \\
TLI & $>=.90$ & .938 & $(2010)$ \\
& $>=.90$ & .945 & Im and Grover (2004) \\
CFI & $<.08$ & .054 & Hair et al. (2010) \\
RMSEA & $=<.090$ & .053 & Byrne (2010) \\
SRMR & & & \\
\hline
\end{tabular}

Note. $\chi 2$ : chi- square; df: degree of freedom; GFI: goodness of fit; AGFI: Adjusted GFI; IFI: Incremental fit index; TLI: Tucker-Lewis Index; CFI: Comparative fit index; RMSEA: Root mean squared error of approximation; SRMR: Standardized toot mean squared residual

\subsection{Measurement model}

A measurement model estimates the relationship between unobserved (constructs) and manifests variables (items) (Hair, Black, Babin, \& Anderson, 2010). This sub-model is used to measure construct validity, which includes discriminate and convergent validities (Harrington, 2009). To assess construct validity, a measurement model uses confirmatory factor analysis (CFA; Harrington, 2009). In fact, CFA tests whether the items measure the construct of the study (Wang \& Wang, 2012). In the present study, to examine the 
fitness of measurement model seven indices were assessed: $\chi 2, \chi^{2} / \mathrm{df}$, goodness of fit (GFI), Adjusted GFI, Incremental fit index (IFI), Tucker-Lewis Index (TFI), Comparative fit index (CFI), Root mean squared error of approximation (RMSEA), Standardized toot mean squared residual (SRMR). As Table 4 shows, all indices followed the criteria. Therefore, the proposed measurement model is fit.

To investigate construct validity, convergent and discriminant validities were examined. Convergent validity determines the value of common variance in indicators/items of each construct. Hair et al. (2010) suggest three ways through which convergent validity is estimated: Factor Loading, Average Variance Extracted (AVE), and Construct Reliability (CR). As Table 5 and Table 6 report, in the present study all the constructs enjoyed convergent validity.

Table 5

Item and factor loading

\begin{tabular}{|c|c|c|c|}
\hline Code & Item & Source & Loading \\
\hline TS1 & $\begin{array}{l}\text { I can rely on the technical support group while } \\
\text { using PutraLMS. }\end{array}$ & Self-developed & 742 \\
\hline TS2 & $\begin{array}{l}\text { Email inquiries to the technical support group can } \\
\text { be made when there is a technical problem while } \\
\text { using PutraLMS. }\end{array}$ & $\begin{array}{l}\text { Sánchez and Hueros } \\
\text { (2010) }\end{array}$ & .850 \\
\hline TS3 & $\begin{array}{l}\text { Web-based inquiries can be made when there is a } \\
\text { technical problem while using putraLMS. }\end{array}$ & $\begin{array}{l}\text { Sánchez and Hueros } \\
(2010)\end{array}$ & .795 \\
\hline TS4 & PutraLMS offers good technical support. & $\begin{array}{l}\text { Sánchez and Hueros } \\
(2010)\end{array}$ & .745 \\
\hline SI1 & $\begin{array}{l}\text { I can see the features of collaborative learning } \\
\text { (e.g. group work) in PutraLMS. }\end{array}$ & Self-developed & .788 \\
\hline SI2 & $\begin{array}{l}\text { The communication tools (email, forum, chat- } \\
\text { room, etc.) in PutraLMS are effective. }\end{array}$ & Pituch and Lee (2006) & .858 \\
\hline SI3 & $\begin{array}{l}\text { PutraLMS enables interactive communication } \\
\text { among students. }\end{array}$ & Pituch and Lee (2006) & .876 \\
\hline SI4 & $\begin{array}{l}\text { I can share my knowledge with my classmates } \\
\text { through PutraLMS }\end{array}$ & Self-developed & .767 \\
\hline PEU1 & I believe that PutraLMS is easy to use. & $\begin{array}{l}\text { Sánchez and Hueros } \\
\text { (2010) }\end{array}$ & .752 \\
\hline PEU2 & $\begin{array}{l}\text { PutraLMS is easy to handle whenever I encounter } \\
\text { a problem. }\end{array}$ & $\begin{array}{l}\text { Liu, Chen, Sun, } \\
\text { Wible, and Kuo } \\
\text { (2010) }\end{array}$ & .799 \\
\hline PEU3 & Learning to use PutraLMS is easy for me. & $\begin{array}{l}\text { Sánchez and Hueros } \\
(2010)\end{array}$ & .759 \\
\hline PEU4 & It is easy to get materials from PutraLMS. & $\begin{array}{l}\text { Sánchez and Hueros } \\
\text { (2010) }\end{array}$ & .782 \\
\hline PU1 & PutraLMS is beneficial for my learning. & $\begin{array}{l}\text { Sánchez and Hueros } \\
\text { (2010) }\end{array}$ & .775 \\
\hline PU2 & $\begin{array}{l}\text { Using PutraLMS improves my academic } \\
\text { achievement. }\end{array}$ & $\begin{array}{l}\text { Sánchez and Hueros } \\
\text { (2010) }\end{array}$ & .769 \\
\hline PU3 & $\begin{array}{l}\text { PutraLMS makes it easier for me to learn at } \\
\text { university. }\end{array}$ & $\begin{array}{l}\text { Sánchez and Hueros } \\
\text { (2010) }\end{array}$ & .794 \\
\hline PU4 & $\begin{array}{l}\text { PutraLMS gives me more control over my } \\
\text { learning. }\end{array}$ & $\begin{array}{l}\text { Sánchez and Hueros } \\
(2010)\end{array}$ & .808 \\
\hline PU5 & PutraLMS helps me to learn more efficiently. & $\begin{array}{l}\text { Sánchez and Hueros } \\
\text { (2010) }\end{array}$ & .895 \\
\hline PU6 & $\begin{array}{l}\text { PutraLMS system makes my learning more } \\
\text { effective. }\end{array}$ & $\begin{array}{l}\text { Sánchez and Hueros } \\
\text { (2010) }\end{array}$ & .878 \\
\hline
\end{tabular}


PU7 PutraLMS has a positive effect on my learning.

Pituch and Lee (2006) $\quad .789$

LMSU1 I send messages to my classmates/ lecturers

Self-developed

LMSU2 I use PutraLMS to download course materials uploaded by my lecturers.

LMSU3 I use PutraLMS to discuss topics of my studies with my classmates.

LMSU4 I use PutraLMS to take quizzes.

Wang and Wang

(2009)

Wang and Wang

(2009)

Self-developed

LMSU5 I use PutraLMS to communicate with my classmates.

Wang and Wang

LMSU6 I use the chat room to communicate with my peers/ lecturers through PutraLMS.

BI1 I intend to increase the use of PutraLMS in the

Self-developed

Wang and Wang

BI2 I intend to continue using PutraLMS every semester.

Venkatesh, Thong, $\quad .825$

BI3 I intend to use PutraLMS more in my learning and $\mathrm{Xu}$ (2012)

Wang and Wang $\quad .849$

(2009)

Venkatesh et al. $\quad .856$

BI4 I will always try to use PutraLMS as part of my daily activities.

BI5 I intend to learn more about the features of

Self-developed

BI6 I would recommend others to use PutraLMS.

Self-developed

Note. TS: technical support; SI: system interactivity; PEU: perceived ease of use; PU: perceived usefulness; LMSU: LMS use; BI: behavioral intention to use

Table 6

Convergent validity of proposed measurement model

\begin{tabular}{lcc}
\hline Constructs & Composite Reliability>0.7 & Average Variance Extracted $>0.5$ \\
\hline Technical support & 0.904 & 0.615 \\
System interactivity & 0.914 & 0.678 \\
Perceived ease of use & 0.904 & 0.598 \\
Perceived usefulness & 0.952 & 0.667 \\
LMS use & 0.893 & 0.667 \\
Behavioral intention to use & 0.893 & 0.667 \\
\hline
\end{tabular}

Discriminant validity measures the distinctness of constructs from each other. In the present study, to assess discriminant validity, in each construct the square roots of the AVE were compared to inter-construct correlation. According to Fornell and Larcker (1981) and Urbach, Smolnik, and Riempp (2010), discriminant validity will be met, if the square root of AVE is higher than inter-construct correlation. Besides, to meet sufficient dissimilarity, Urbach et al. (2010) suggest factor loadings equal to or more than .70 . Table 7 indicates the matrix of inter-construct correlation in which the terms of the diagonal are the square root of AVE in each construct. As Table 7 indicates, the square root of AVE in each construct is higher than inter-construct correlation. Therefore, discriminant validity was met. 
Table 7

Discriminant validity for the measurement model

\begin{tabular}{cllllll}
\hline Variables & BI & LMSU & PU & PEU & SI & TS \\
\hline BI & .817 & & & & & \\
LMSU & .545 & .817 & & & & \\
PU & .521 & .332 & .817 & & & \\
PEU & .389 & .211 & .506 & .773 & .824 & \\
SI & .306 & .225 & .590 & .434 & .784 \\
TS & .293 & .230 & .438 & .489 & .603 & .78 : \\
\hline Note. BI: behavioral intention to use; LMSU: LMS use; PU: perceived usefulness; PEU: perceived \\
ease of use; SI: system interactivity; TS: technical support
\end{tabular}

\subsection{Structural model}

After assessing the measurement model, the structural model should be tested based on the theoretical model. The structural model, unlike the measurement model, investigates the effect of one construct on the other (Wang \& Wang, 2012). As mentioned earlier, in the present study, to investigate the relationship between the constructs of technical support, system interactivity, perceived ease of use, perceived usefulness, behavioral intention to use and LMS use, eight hypotheses were formed. To test the hypotheses of the proposed structural model, at first the fitness of the model should be examined. Table 8 reports the indices of proposed structural model. All the indices for proposed structural model followed the criteria. Therefore, the proposed structural model is fit.

Table 8

Fit indices of proposed structural model

\begin{tabular}{llll}
\hline Model Fit Indices & Criteria & Values & References \\
\hline$\chi^{2}$ & Insignificant, significant & Insignificant & Hair et al. (2010) \\
& value can be expected & & \\
$\chi 2 / \mathrm{df}$ & $=<2$ & 1.647 & Im and Grover (2004) \\
GFI & Near to .90 & .875 & Schumacker and Lomax (2010) \\
AGFI & $=<.08$ & .803 & Im and Grover (2004) \\
IFI & Near to .90 & .943 & Meyers, Gamst, and Guarino \\
& & & (2006) \\
TLI & $=<.90$ & .937 & Schumacker and Lomax (2010) \\
CFI & $=<.90$ & .942 & Im and Grover (2004) \\
RMSEA & $<.08$ & .055 & Hair et al. (2010) \\
SRMR & $=<.090$ & .066 & Byrne (2010) \\
\hline
\end{tabular}

Note. 2 2: chi- square; $d f$ : degree of freedom; GFI: goodness of fit; AGFI: Adjusted GFI; IFI: Incremental fit index; TLI: Tucker-Lewis Index; CFI: Comparative fit index; RMSEA: Root mean squared error of approximation; SRMR: Standardized toot mean squared residual

Table 9 reports the Standard Regression Weights and path significant. As Table 9 reports, the path linking system interactivity to perceived ease of use and the path linking technical support to perceived usefulness were not significant. Therefore, the second and third hypotheses were not supported. However, system interactivity had a significant 
effect on perceived usefulness $(\beta=.511, \mathrm{p}<.001)$; technical support had a significant effect on perceived ease of use $(\beta=.313, \mathrm{p}<.001)$; perceived ease of use had a significant effect on perceived usefulness $(\beta=.343, p<.001)$; perceived usefulness has a significant effect on behavioral intention to use $(\beta=.437, \mathrm{p}<.001)$; perceived ease of use had a significant effect on behavioral intention to use $(\beta=.169, \mathrm{p}<.05)$; and behavioral intention to use had a significant effect on LMS use $(\beta=.547, \mathrm{p}<.001)$.

Table 9

Standard regression weights for proposed structural model

\begin{tabular}{ccccc}
\hline Hypothesis & Path & Path coefficient & t-value & Results \\
\hline $\mathrm{H}_{1}$ & $\mathrm{SI} \longrightarrow \mathrm{PU}$ & $.511 * * *$ & 5.460 & Supported \\
$\mathrm{H}_{2}$ & $\mathrm{SI} \longrightarrow \mathrm{PEU}$ & .043 & .421 & Not Supported \\
$\mathrm{H}_{3}$ & $\mathrm{TS} \longrightarrow \mathrm{PU}$ & .131 & 1.551 & Not Supported \\
$\mathrm{H}_{4}$ & $\mathrm{TS} \longrightarrow \mathrm{PEU}$ & $.313 * * *$ & 3.311 & Supported \\
$\mathrm{H}_{5}$ & $\mathrm{PEU} \longrightarrow \mathrm{PU}$ & $.343^{* * *}$ & 3.898 & Supported \\
$\mathrm{H}_{6}$ & $\mathrm{PU} \longrightarrow \mathrm{BI}$ & $.437 * * *$ & 5.293 & Supported \\
$\mathrm{H}_{7}$ & $\mathrm{PEU} \longrightarrow \mathrm{BI}$ & $.169 *$ & 2.132 & Supported \\
$\mathrm{H}_{8}$ & $\mathrm{BI} \longrightarrow \mathrm{LMSU}$ & $.547 * * *$ & 7.141 & Supported \\
\hline
\end{tabular}

Note. Path S.: Path Significant; *** $p<.001 ; * P<.05 ;$ SI: system interactivity; TS: technical support; PU: perceived usefulness; PEU: perceived ease of use; BI: behavioral intention to use; LMSU: LMS use

Fig. 4 illustrates the results of hypothesis testing. As Fig. 4 shows, the proposed structural model explained $36 \%$ of variance in perceived usefulness and $35 \%$ of variance in perceived ease of use. The proposed structural model was also able to explain $25.5 \%$ of variance in behavioral intention to use and $30 \%$ of variance in LMS use.

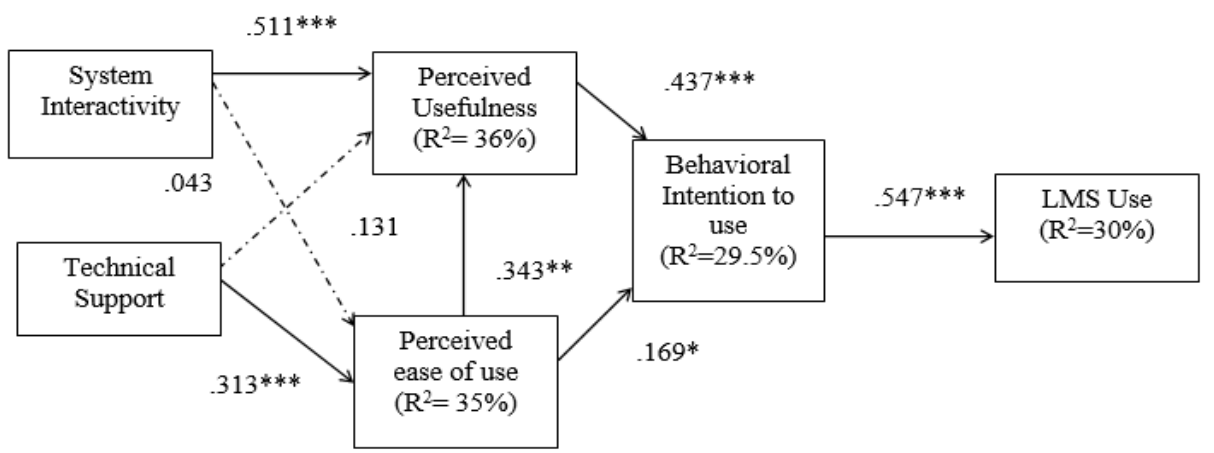

Fig. 4. Hypothesis testing results (Path Significant: *** $\mathrm{p}<.001 ; * \mathrm{P}<.05$ ) 


\section{Discussion}

In the present study, the proposed structural model investigated the relationship between the constructs of system interactivity, technical support, perceived ease of use, perceived usefulness, behavioral intention to use, and LMS use through eight paths. The results of the study revealed that system interactivity had a significant effect on perceived usefulness, but not on perceived ease of use. This result suggests improving the interactivity of the LMS may increase the usefulness of the system.

The results of previous studies are inconclusive. For example, Pituch and Lee (2006) investigated LMS utilization among 259 college students in Taiwan and found out that the effect of system interactivity on perceived ease of use was not significant, while the effect of system interactivity on perceived usefulness was significant. There are also several previous studies that considered system interactivity as one of the dimensions of system characteristics and found that system characteristics had a significant effect on both perceived usefulness and perceived ease of use (Igbaria et al., 1995; Ke et al., 2012). In general, system characteristics is one the crucial factors that influences system use and beliefs of system users (Pituch \& Lee, 2006). In the present study, system interactivity could explain $36 \%$ variance of perceived usefulness. This result confirms the role of system characteristics in using LMS by higher education students.

The outcomes of the present study revealed that technical support had a significant effect on perceived ease of use, while the effect of technical support on perceived usefulness was not significant. The results of previous research had indicated that technical support affects both perceived usefulness and perceived ease of use (Ngai et al., 2007; Sánchez \& Hueros, 2010). Technical support is regarded as assisting students to solve hardware and software problems with LMS. In the present study, technical support explained $35 \%$ variance of perceived ease of use. Therefore, this result recommends that to enhance the LMS use of students, it is essential for universities to support students to overcome hardware and software problems with LMS.

In addition, the outcomes of the present study provide insights into educational management at universities. The results of the research indicated that perceived ease of use and perceived usefulness had a crucial role in using LMS. Additionally, behavioral intention to use acted as a bridge between beliefs (perceived ease of use and perceived usefulness) and system utilization. This result suggests that increasing LMS utilization among students, fostering perceived ease of use, and perceived usefulness would be necessary. In other words, in views of students, a system which is hard to use would decrease the intention of students to use it.

\section{Conclusion}

The present study proposed a model for explaining and predicting Learning Management System adoption among Malaysian undergraduate students based on Technology Acceptance Model. The result of SEM revealed that among the eight hypotheses, six were supported while two were not. This study has some limitations. First of all, this study investigated LMS utilization among higher education students. Hence, the findings of the study may not be generalizable to instructors or other academic environments such as elementary or high schools. The present study was also limited to two external variables of system interactivity and technical support. There are a variety of external variables such as background of students, self-efficacy, system quality, system response and so on which may affect LMS adoption by students. In fact, the proposed structural 
model could explain and predict $30 \%$ of variance in LMS utilization. In other words, $70 \%$ of variance in LMS utilization is still not explained. Therefore, it is recommended that further research consider more exogenous variables and test the model in different contexts. This study was limited to investigation of one of the public universities located in the Province of Selangor. It is recommended that future studies focus on the other public or private universities and examine the performance of their LMS on learning. PutraLMS is a system developed by local vendors, so it is recommended that future studies examine open source LMSs or popular brands of LMS such as Blackboard (Bb) and WebCT. The model of the study was limited to Technology Acceptance Model. It is recommended that future studies investigate LMS adoption through other models such as Innovation and Diffusion Theory (IDT) and Task-Technology Fit. Finally, it should be mentioned once again that through the demographic information collected, about 90 percent of the participants responded that using LMS was not compulsory in their courses, while 10 percent responded that using LMS was compulsory in certain courses. This variable may have influenced the results of the research.

\section{References}

Adzharuddin, N. A., \& Ling, L. H. (2013). Learning management system (LMS) among university students: Does it work? International Journal of e-Education, e-Business, e-Management and e-Learning, 3(3), 248-252.

Al-Busaidi, K. A., \& Al-Shihi, H. (2012). Critical factors influencing instructors' acceptance and use of learning management systems. In R. Babo \& A. Azevedo (Eds.), Higher Education Institutions and Learning Management Systems (pp. 116140). Hershey, PA: Information Science Reference.

Álvarez, A., Martín, M., Fernández-Castro, I., \& Urretavizcaya, M. (2013). Blending traditional teaching methods with learning environments: Experience, cyclical evaluation process and impact with MAgAdI. Computers \& Education, 68, 129-140.

Ayub, A. F. M., Tarmizi, R. A., Jaafar, W. M. W., Ali, W. Z. W., \& Luan, W. S. (2010). Factors influencing students' use a learning management system portal: Perspective from higher education students. International Journal of Education and Information Technologies, 4(2), 100-108.

Bannan-Ritland, B. (2002). Computer-mediated communication, elearning, and interactivity: A review of the research. Quarterly Review of Distance Education, 3(2), 161-179.

Blessing, L. T. M., \& Chakrabarti, A. (2009). DRM: A design research methodology. London: Springer.

Byrne, B. M. (2010). Structural equation modeling with AMOS: Basic concepts, applications, and programming (2nd ed.). New York, NY: Routledge.

Chang, C. L. (2008). Faculty perceptions and utilization of a learning management system in higher education. Doctoral dissertation, Ohio University, USA.

Chou, C. (2003). Interactivity and interactive functions in Web-based learning systems: A technical framework for designers. British Journal of Educational Technology, 34(3), 265-279.

Connolly, T., Gould, C., Baxter, G., \& Hainey, T. (2012). Learning 2.0: Using web 2.0 technologies for learning in an engineering course. In R. Babo \& A. Azevedo (Eds.), Higher Education Institutions and Learning Management Systems (pp. 50-73). Hershey, PA: Information Science Reference.

Davis, F. D. (1986). A technology acceptance model for empirically testing new end-user information systems: Theory and results. Doctoral dissertation, Sloan School of Management, Massachusetts Institute of Technology, USA. 
Davis, F. D., Bagozzi, R. P., \& Warshaw, P. R. (1989). User acceptance of computer technology: A comparison of two theoretical models. Management Science, 35(8), 982-1003.

Dutta, A., Roy, R., \& Seetharaman, P. (2013). Course management system adoption and usage: A process theoretic perspective. Computers in Human Behavior, 29(6), 25352545.

Dżega, D., \& Pietruszkiewicz, W. (2012). The technological advancement of LMS systems and e-content software. In R. Babo \& A. Azevedo (Eds.), Higher Education Institutions and Learning Management Systems (pp. 219-245). Hershey, PA: Information Science Reference.

Embi, M. A., Wahab, Z. A., Sulaiman, A. H., \& Atan, H. (2011). Introduction. In M. A. Embi (Ed.). e-Learning in Malaysian Higher Education Institutions: Status, Trends, and Challenges (pp.1-4). Department of Higher Education, Ministry of Higher Education.

Evans, C., \& Gibbons, N. J. (2007). The interactivity effect in multimedia learning. Computers \& Education, 49(4), 1147-1160.

Fishbein, M., \& Ajzen, I. (1975). Belief, attitude, intention and behavior: An introduction to theory and research. Menlo Park, CA: Addison-Wesley Publishing Company.

Folden, R. W. (2012). General perspective in learning management systems. In R. Babo \& A. Azevedo (Eds.), Higher Education Institutions and Learning Management Systems (pp.1-27). Hershey, PA: Information Science Reference.

Fornell, C., \& Larcker, D. F. (1981). Evaluating structural equation models with unobservable variables and measurement error. Journal of Marketing, 18(1), 39-50.

Futris, T. G., Schramm, D. G., Richardson, E. W., \& Lee, T. K. (2015). The impact of organizational support on the transfer of learning to practice. Children and Youth Services Review, 51, 36-43.

Ghavifekr, S., \& Mahmood, H. (2017). Factors affecting use of e-learning platform (SPeCTRUM) among University students in Malaysia. Education and Information Technologies, 22(1), 75-100. doi: 10.1007/s10639-015-9435-Z

Grigorovici, D., Nam, S., \& Russill, C. (2003). The effects of online syllabus interactivity on students' perception of the course and instructor. The Internet and Higher Education, 6, 41-52.

Hair, J. F., Black, W. C., Babin, B. J., \& Anderson, R. E. (2010). Multivariate data analysis: A global perspective (7th ed.). New Jersey: Prentice-Hall.

Hair, J. F., Hult, G. T. M., Ringle, C. M., \& Sarstedt (2014). A primer on partial least squares structural equation modeling (PLS-SEM). Los Angeles: Sage.

Hamat, A., Embi, M. A., \& Sulaiman, A. H. (2011). Learning management systems in Malaysian higher education institutions. In M. A. Embi (Ed.), e-Learning in Malaysian Higher Education Institutions: Status, Trends, and Challenges (pp. 29-51). Department of Higher Education, Ministry of Higher Education.

Harrington, D. (2009). Confirmatory factor analysis: Pocket guides to social work research methods. New York: Oxford University Press.

Hernandez, B., Montaner, T., Sese, F. J., \& Urquizu, P. (2011). The role of social motivations in e-learning: How do they affect usage and success of IC interactive tools? Computers in Human Behavior, 27(6), 2224-2232.

Hilmi, M. F., Pawanchik, S., \& Mustapha, Y. (2012). Perceptions on service quality and ease-of-use: Evidence from Malaysian distance learners. Malaysian Journal of Distance Education, 14(1), 99-110.

Ho, R. (2006). Handbook of univariate and multivariate data analysis and interpretation with SPSS. New York: CRC Press.

Igbaria, M., Guimaraes, T., \& Davis, G. B. (1995). Testing the determinants of 
microcomputer usage via a structural equation model. Journal of Management Information Systems, 11(4), 87-114.

Im, K. S., \& Grover, V. (2004). The use of structural equation modeling in IS research. In M. E. Whitman \& A. B. Woszczynski (Eds.), The Handbook of Information Systems Research (pp. 44-65). Hershey, PA: Idea group publishing.

Ioannou, A., \& Hannafin, R. (2008). Deficiencies of course management systems: Do students care? The Quarterly Review of Distance Education, 9(4), 415-425.

Islam, A. K. M. N. (2013). Investigating e-learning system usage outcomes in the university context. Computers \& Education, 69, 387-399.

Ke, C. H., Sun, H. M., \& Yang, Y. C. (2012). Effects of user and system characteristics on perceived usefulness and perceived ease of use for the web-based classroom response system. The Turkish Online Journal of Educational Technology, 11(3), 128143.

Kenny, D. A. (2014). Mediation. Retrieved from http://davidakenny.net/cm/mediate.htm

Klopping, I. M., \& McKinney, E. (2004). Extending the technology acceptance model and the task-technology fit model to consumer e-commerce. Information Technology, Learning, and Performance Journal, 22(1), 35-48.

Krysik, J. L., \& Finn, J. (2010). Research for effective social work practice (2nd ed.) New York: Routledge.

$\mathrm{Ku}, \mathrm{C} . \mathrm{-H}$. (2009). Extending the technology acceptance model using perceived user resources in higher education web-based online learning courses. Doctoral dissertation, The University of Central Florida, USA.

Lee, C.-H., Chan, J. J., Thanimalay, N., \& Lim, J.-T. (2012). Study of student preferences in using the university default learning management system versus the weblog in learning and teaching. In Proceedings of the 7th international conference on $e$ learning (pp. 251-258). Reading, UK: Academic Publishing.

Leech, N. L., Barrett, K. C., \& Morgan, G. A. (2008). SPSS for intermediate statistics: Use and interpretation. New York: Routledge.

Liu, I.-F., Chen, M. C., Sun, Y. S., Wible, D., \& Kuo, C.-H. (2010). Extending the TAM model to explore the factors that affect intention to use an online learning community. Computers \& Education, 54(2), 600-610.

Lonn, S., \& Teasley, S. D. (2009). Saving time or innovating practice: Investigating perceptions and uses of learning management systems. Computers \& Education, 53(3), 686-694.

Ma, Q., Chan, A. H. S., \& Chen, K. (2016). Personal and other factors affecting acceptance of smartphone technology by older Chinese adults. Applied Ergonomics, 54, 62-71. doi: 10.1016/j.apergo.2015.11.015

Marsh, H. W., Hau, K. T., \& Wen, Z. (2004). In search of golden rules: Comment on hypothesis-testing approaches to setting cutoff values for fit indexes and dangers in overgeneralizing $\mathrm{Hu}$ and Benler's (1999) findings. Structural Equation Modeling, 11(3), 320-341.

Meyers, L. S., Gamst, G., \& Guarino, A. J. (2006). Applied multivariate research: Design and interpretation. Thousand Oaks, CA: Sage Publications.

Moore, M. G. (1989). Editorial: Three types of interaction. American Journal of Distance Education, 3(2), 1-7.

Motaghian, H., Hassanzadeh, A., \& Moghadam, D. K. (2013). Factors affecting university instructors' adoption of web-based learning systems: Case study of Iran. Computers \& Education, 61, 158-167.

Nair, P. K., Ali, F., \& Leong, L. C. (2015). Factors affecting acceptance \& use of ReWIND: Validating the extended unified theory of acceptance and use of technology. Interactive Technology and Smart Education, 12(3), 183-201.

Ngai, E. W. T., Poon, J. K. L., \& Chan, Y. H. C. (2007). Empirical examination of the 
adoption of WebCT using TAM. Computers \& Education, 48(2), 250-267.

Nijman, D. J., \& Gelissen, J. (2011). Direct and indirect effects of supervisor support on transfer of training. In R. F. Poell \& van Woerkon (Eds.), Supporting Workplace Learning (pp. 89-106). Netherlands: Springer.

Northrup, P. T. (2002). Online learners' preferences for interaction. Quarterly Review of Distance Education, 3(2), 219-226.

Offredy, M., \& Vickers, P. (2010). Developing a healthcare research proposal: An interactive student guide. Oxford: Wiley-Blackwell.

Piotrowski, M. (2010). What is an e-learning platform? In Y. Kats (Ed.), Learning Management System Technologies and Software Solutions for Online Teaching: Tools and Applications (pp. 20-36). Hershey, PA: Information Science Reference.

Pituch, K. A., \& Lee, Y-K. (2006). The influence of system characteristics on e-learning use. Computers \& Education, 47(2), 222-244.

Proske, A., Narciss, S., \& Korndle, H. (2007). Interactivity and learners' achievement in Web-based learning. Journal of Interactive Learning Research, 18(4), 511-531.

Puteh, M. (2007). E-learning in Malaysia public universities: Case studies of Universiti Kebangsaan Malaysia and Universiti Teknologi Malaysia. In Proceedings of the first International Malaysian Educational Technology convention (pp. 825-834). Johor Bahru, Malaysia.

Putra Learning Management System. (2013). PuraLMS user manual. Retrieved from http://www.lms.upm.edu.my/i3learn/www/help.htm

Rahman, K., A., Ghazali, S. A. M., \& Ismail, M. N. (2010). The effectiveness of learning management system (LMS): Case study at Open University Malaysia (OUM), Kota Bharu Campus. Journal of Emerging Trends in Computing and Information Sciences, 2(2), 73-79.

Rodríguez-Ardura, I., \& Meseguer-Artola, A. (2015). e-Learning continuance: The impact of interactivity and the mediating role of imagery, presence and flow. Information \& Management, 53(4), 504-516. doi: 10.1016/j.im.2015.11.005

Sánchez, R. A., \& Hueros, A. D. (2010). Motivational factors that influence the acceptance of Moodle using TAM. Computers in Human Behavior, 26(6), 1632-1640.

Schumacker, R. E., \& Lomax, R. G. (2010). A beginner's guide to structural equation modelling (3rd ed.). New York, NY: Routledge.

Stantchev, V., Colomo-Palacios, R., Soto-Acosta, P., \& Misra, S. (2014). Learning management systems and cloud file hosting services: A study on students' acceptance. Computers in Human Behavior, 31, 612-619.

Su, B., Bonk, C. J., Magjuda, R. J., Liu, X., \& Lee, S. (2005). The importance of interaction in web-based education: A program-level case study of online MBA courses. Journal of Interactive Online Learning, 4(1), 1-19.

Sulaiman, F. (2013). Malaysian undergraduate science physics students' and pre-service science teachers' perceptions of online learning. Basic Research Journal of Education Research and Review, 2(5), 76-80.

Šumak, B., Heričko, M., \& Pušnik, M. (2011). A meta-analysis of e-learning technology acceptance: The role of user types and e-learning technology types. Computers in Human Behavior, 27(6), 2067-2077.

Sun, J. N., \& Hsu, Y. C. (2013). Effect of interactivity on learner perceptions in Webbased instruction. Computers in Human Behavior, 29(1), 171-184. doi: 10.1016/j.chb.2012.08.002.

Sundar, S. S., Kalyanaraman, S., \& Brown, J. (2003). Explicating website interactivity: Impression-formation effects in political campaign sites. Communication Research, 30(1), 30-59.

Thorson, K. S., \& Rodgers, S. (2006). Relationships between blogs as eWOM and 
interactivity, perceived interactivity, and parasocial interaction. Journal of Interactive Advertising, 6(2), 5-44.

Thurmond, V. A., \& Wambach, K. (2004). Understanding interactions in distance education: A review of the literature. International Journal of Instructional Technology and Distance Learning, 1, 9-33.

Urbach, N., Smolnik, S., \& Riempp, G. (2010). An empirical investigation of employee portal success. Journal of Strategic Information Systems, 19(3), 184-206.

Venkatesh, V., \& Bala, H. (2008). Technology acceptance model 3 and a research agenda on interventions. Decision Sciences, 39(2), 273-315.

Venkatesh, V., \& Davis, F. D. (2000). A theoretical extension of the technology acceptance model: Four longitudinal field studies. Management Science, 46(2), 186204.

Venkatesh, V., Thong, J. Y. L., \& Xu, X. (2012). Consumer acceptance and use of information technology: Extending the unified theory of acceptance and use of technology. MIS Quarterly, 36(1), 157-178.

Wang, J., \& Wang, X. (2012). Structural equation modelling: Applications using M plus. West Sussex: Wiley.

Wang, W.-T., \& Wang, C.-C. (2009). An empirical study of instructor adoption of webbased learning systems. Computers \& Education, 53(3), 761-774. 